\title{
Biotechnology for production of recombinant hybrid proteins from plants and microbes with antifungal activity
} Rogozin E.

Shemyakin-Ovchinnikov Institute of Bioorganic Chemistry Russian Academy of Sciences, Moscow, Russia; Gause Institute of New Antibiotics, Moscow, Russia; Institute of Ecological and Agricultural Biology (X-Bio) Tyumen State University, Tyumen, Russia

E-mail: rea21@list.ru; globodera@gmail.com

Key message. The principle of obtaining recombinant antimicrobial polypeptides from plant and microbial origins as a part of chimeric proteins with thioredoxin by heterologous expression in a prokaryotic system is presented. The results obtained in terms of their antifungal activity in relation to plant pathogenic micromycetes allow us to consider these compounds as prototypes of some active substances of environmentally friendly biofungicides, as well as possible components of hybrid plant protection products against fungal diseases.

Keywords: antimicrobial peptides, recombinant hybrid proteins, antifungal activity, natural sources, biological plant protection. It is well known that the main way to limit the spread of diseases of cultivated plants caused by plant pathogenic microorganisms is usage of chemical plant protection products, many of which are currently ineffective because of resistance to them, in addition, they have a number of limitations in their ecotoxicological component. Background of these problems, the biological method comes to the fore as one of the ways to solve the indicated limitations, as well as increasing the degree of greening of crop production. In the traditional aspect, the biomethod in plant protection from diseases is an application of antagonistic microorganisms (bacteria, actinomycetes, fungi) to the corresponding plant pathogens, while in the overwhelming majority of cases, molecular tools and mechanisms of such action remain outside the scope of attention: the achievement of the expected effect. However, in recent years, the emphasis has focused more on the study of the composition of biologically active metabolites, including those with antimicrobial properties. It was previously shown that the antimicrobial peptides from plants and certain microorganisms are a competitive alternatives to many active substances of fungicides and antibiotics used in agriculture, but it is no secret that the prospects for their commercialization are faced with a number of limitations, in particular, due to the potential high cost of production and, as a result, the selling price. Our approach is based on production of target active peptides in recombinant form through microbiological synthesis in a prokaryotic expression system; the active compound is integrated in the composition of the chimeric protein in combination with the so-called "anchor protein" - thioredoxin. In a series of comparative experiments to determine the antifungal activity of such chimeric, or hybrid, proteins with respect to single peptides, they showed their ability to inhibit phytopathogens. Thus, recombinant hybrid proteins containing an antimicrobial component of originally natural origin can be considered as prototypes of the active substances of "new generation" biofungicides, the cost of production of which will be significantly reduced relative to peptides.

This work was supported by the Russian Foundation for Basic Research (grant № 18-34-20058-mol_a_ved).

\section{Биотехнология получения рекомбинантных гибридных белков растений и микроорганизмов с антифунгальными свойствами Рогожин Е.A.}

ФГБНУ Институт биоорганической химии им. М.М. Шемякина и Ю.А. Овчинникова РАН, Москва, Россия; ФГБУ «Научноисследовательский Институт по изысканию новых антибиотиков им. Г.Ф. Гаузе», Москва, Россия; Институт экологической и сельскохозяйственной биологии (X-Bio), Тюменский государственный университет, Тюмень, Россия

\begin{abstract}
Аннотация. Представлен приниип получения рекомбинантных антимикробных полипептидов растительного и микробного происхождения в составе химерных белков с тиоредоксином путем гетерологической экспрессии в прокариотической системе. Полученные результаты по уровню их антифунгальной активности по отночению к фитопатогенным микромицетам позволяет рассматривать данные соединения как прототипь действующих веществ экологически безопасных биофунгицидов, а также в качестве возможных компонентов гибридных средств зашчиты растений от грибных болезней.
\end{abstract}

Ключевые слова: антимикробные пептиды, рекомбинантные гибридные белки, антифунгальная активность, природные источники, биологическая зашита растений.

Хорошо известно, что основным способом ограничения распространения болезней культурных растений, вызываемых фитопатогенными микроорганизмами, является применение химических средств защиты растений, многие из которых в настоящее время малоэффективны по причине возникновения к ним резистентности, кроме того, они имеют ряд ограничений по своей экотоксилогической составляющей. На фоне указанных проблем биологический метод выходит на первый план как один из способов решения обозначенных ограничений, а также повышения степени экологизации продукции растениеводства. В традиционном понимании биометод в защите растений от болезней - это, как правило, применение микроорганизмовантагонистов (бактерий, актиномицетов, грибов) соответствующим фитопатогенам, при этом в подавляющем большинстве случаев молекулярные инструменты и механизмы такого действия остаются за пределами внимания: определяющим является достижение ожидаемого эффекта. Однако в последние годы акцент в большей степени концентрируется на исследовании состава биологически активных метаболитов, в том числе обладающих антимикробными свойствами. Ранее показано, что антимикробные пептиды растений и некоторых микроорганизмов представляют собой конкурентную альтернативу многим действующим веществам фунгицидов и антибиотиков, применяемых в сельском хозяйстве, однако не секрет, что перспективы их коммерциализации сталкиваются с рядом ограничений, в частности, по причине потенциальной высокой стоимости производства и, как следствие, отпускной цены. Предлагаемый нами подход основан на производстве целевых активных пептидов в рекомбинантной форме посредством микробиологического синтеза в прокариотической системе экспрессии; при этом активный компонент интегрирован в составе химерного белка в комплексе с так называемым «якорным белком» - тиоредоксином. В серии сравнительных экспериментов по определению антифунгальной активности таких химерных, или гибридных, белков относительно только одних пептидов показало наличие у них свойств ингибировать фитопатогены. Таким образом, рекомбинантные гибридные белки, содержащие в своем составе антимикробный компонент изначально природного происхождения, можно рассматривать как прототипы действующих веществ биофунгицидов «нового поколения», себестоимость производства которых будет значительно снижена относительно пептидов. Данная работа поддержана Российским фондом фундаментальных исследований (грант № 18-3420058-мол а вед). 